\title{
Amino Acid Sequence of the Active Site of Human Serum Cholinesterase from Usual, Atypical, and Atypical-Silent Genotypes
}

\author{
Oksana Lockridge ${ }^{1,2}$ and Bert N. La Du ${ }^{1}$
}

Received 6 Dec. 1985-Final 3 Mar. 1986

Active-site tryptic peptides were isolated from three genetic types of human serum cholinesterase. The active-site peptide was identified by labeling the active-site serine with $\left[{ }^{3} \mathrm{H}\right]$ diisopropylfluorophosphate. Peptides were purified by high-performance liquid chromatography. Amino acid composition and sequence analysis showed that the peptide from the usual genotype contained 29 residues with the sequence Ser-Val-Thr-Leu-Phe-Gly-GluSer-Ala-Gly-Ala-Ala-Ser-Val-Ser-Leu-His-Leu-Leu-Ser-Pro-Gly-Ser-HisSer-Leu-Phe-Thr-Arg. The active-site serine was the eighth residue from the $N$-terminal. The peptide containing the active-site serine from the atypical genotype contained 22 residues with the sequence Ser-Val-Thr-Leu-PheGly-Glu-Ser-Ala-Gly-Ala-Ala-Ser-Val-Ser-Leu-His-Leu-Leu-Ser-Pro-Gly. The peptide from the atypical-silent genotype contained eight residues with the sequence Gly-Glu-Ser-Ala-Gly-Ala-Ala-Ser. Thus, the sequences of the atypical and atypical-silent active-site peptides were identical to the corresponding portions of the usual peptide.

KEY WORDS: cholinesterase; active-site sequence.

\section{INTRODUCTION}

Human serum cholinesterase (EC 3.1.1.8; acylcholine acyl hydrolase) is also known as pseudocholinesterase, butyrylcholinesterase, and nonspecific cho-

This work was supported by U.S. Army Medical Research and Development Command Contract DAMD17-82-C-2271 (to O.L.) and NIH Grant GM 27028 (to B.N.L.).

${ }^{1}$ Pharmacology Department, Medical Science I, M6322, University of Michigan, Ann Arbor, Michigan 48109-0010.

${ }^{2}$ To whom correspondence should be addressed. 
linesterase. The genetic variants of human serum cholinesterase were discovered after the drug, succinylcholine, gained widespread use as a muscle relaxant. It was observed that 1 in approximately 2000 patients was unable to breathe for prolonged periods, even hours, after receiving a normal dose of succinylcholine (Kalow and Gunn, 1959). Kalow provided an explanation for this abnormal response by showing that it occurred in persons having an "atypical" form of cholinesterase (Kalow and Gunn, 1957) characterized by a reduced affinity for succinylcholine (Hersh et al., 1974). Later, additional genetic variants were identified. One of these was the "silent" variant which had zero or nearly zero activity (Liddell et al., 1962).

The properties of the atypical cholinesterase variant could be explained by a single amino acid alteration at the anionic site (Kalow and Davies, 1958; Muensch et al., 1978; Lockridge and $\mathrm{La} \mathrm{Du}, 1978$ ). However, to date this has not been established and no amino acid sequence information for any portion of the atypical variant has been published. For the usual cholinesterase the total amino acid sequence information published to date is an 11-residue fragment from the active site (Yamato et al., 1983). Yamato et al. suggested that the single amino acid alteration in atypical cholinesterase was a substitution from Glu to His within their 11-residue active-site peptide. The basis for their suggestion was the difference in electrophoretic mobility of the active site peptides obtained from the usual and atypical cholinesterases. We also found that the usual and atypical active-site peptides had different physical properties, since they eluted at different positions on $\mathrm{HPLC}^{3}$ and had different solubilities. However, we disagree with Yamato's interpretation that the difference is due to an amino acid substitution within the active-site peptide. We found that the usual cholinesterase yielded a 29-residue tryptic peptide, while the atypical and atypical-silent cholinesterases yielded shorter peptides that were not the result of cleavage by trypsin. The sequences of the atypical and atypical-silent active-site peptides were identical to the region around the active-site serine of the usual form of cholinesterase.

\section{EXPERIMENTAL PROCEDURES}

Blood Samples. The source of usual cholinesterase, genotype UU, was outdated human plasma, kindly provided by Dr. Harold Gallick of the Michigan Department of Public Health, Lansing. The source of atypical cholinesterase, genotype AA, was a single female donor with a family history

\footnotetext{
${ }^{3}$ Abbreviations used: DFP, diisopropylfluorophosphate; MP, monoisopropylphosphoryl; SDS, sodium dodecyl sulfate; HPLC, high-performance liquid chromatography; TFA, trifluoroacetic acid; HFBA, heptafluorobutyric acid; PTH, phenylthiohydantoin; A, alanine; E, glutamic acid; F, phenylalanine; G, glycine; H, histidine; L, leucine; P, proline; $R$, arginine; S, serine; $T$, threonine; $\mathrm{V}$, valine.
} 
of succinylcholine apnea. From her activity of $0.53 \mu \mathrm{mol}$ benzoylcholine hydrolyzed $/ \mathrm{min} / \mathrm{ml}$ of serum (Kalow and Lindsay, 1955), her dibucaine number of 24 (Kalow and Genest, 1957), and her fluoride number of 37 (Harris and Whittaker, 1961), it was concluded that she had the AA genotype. Her AA genotype was confirmed by genotyping three generations of family members. Our AA donor underwent plasmaphoresis over a period of 2 years, until 3.5 liters of plasma had accumulated. Plasma was stored at $-20^{\circ} \mathrm{C}$. The source of atypical-silent cholinesterase, genotype AS, was a single male donor who experienced $3 \mathrm{hr}$ of apnea after receiving $120 \mathrm{mg}$ of succinylcholine. He had the characteristic dibucaine number (DN 18), fluoride number (FN 24), and activity $(0.25 \mu \mathrm{mol}$ benzoylcholine $/ \mathrm{min} / \mathrm{ml}$ serum) of the atypical phenotype. Genotyping of three generations of family members revealed that he was heterozygous for atypical-silent cholinesterase. Nine and four-tenths liters of his plasma was collected by plasmaphoresis over a period of 3 years.

Enzyme Purification. The usual cholinesterase was purified by ionexchange chromatography at $\mathrm{pH} 4$ on Whatman DE52, followed by ionexchange chromatography at $p \mathrm{H} \mathrm{7}$, and finally by affinity chromatography on procainamide Sepharose 4B (Lockridge and La $\mathrm{Du}, 1978$ ). The second ion-exchange step could be omitted when the purification on the $p \mathrm{H} 4$ ion-exchange column was 1200 -fold or greater. This degree of purification was not always achieved, and therefore the second ion-exchange step was included. The procainamide step yielded pure enzyme only if the applied enzyme was already at least 1200 -fold pure. A total of 100 liters of plasma was used. Seven and one-half liters of plasma was processed at one time, with a yield of 8 to $12 \mathrm{mg}$ of cholinesterase. On SDS gel electrophoresis the purified usual cholinesterase had a major band with a molecular weight of 90,000. The only other band visible with either silver staining or Coomassie blue staining was a faint dimer band with a molecular weight of 180,000 . The atypical and atypical-silent cholinesterases were purified by similar strategies.

Labeling the Active Site. Three to $64 \mathrm{mg}$ of cholinesterase was treated with 2 equivalents of $\left[{ }^{3} \mathrm{H}\right] \mathrm{DFP}(5.2 \mathrm{Ci} / \mathrm{mmol})$. This amount of DFP brought the enzyme activity to zero. The reaction mixture was incubated for 4 days or more to achieve "aging." During aging the diisopropylphosphate derivative is catalytically converted to the more stable monoisopropylphosphate derivative (Berends et al., 1959). It proved advantageous to have the monoisopropylphosphate derivative because this gave a higher yield of active-site tryptic peptide, and it gave a single radioactive peptide.

Reduction and Alkylation with Iodoacetamide. The aged MP-cholinesterase was concentrated to 1 to $5 \mathrm{mg} / \mathrm{ml}$ and placed inside a glass screw-cap tube. Solid guanidine-HCl (Schwartz-Mann Co., ultrapure, or Pierce Co., 
sequanal grade) was added to a final concentration of $6 \mathrm{M}$, the $p \mathrm{H}$ adjusted to 8.1 with $1 \mathrm{M}$ unneutralized Trizma base, and EDTA added to $4 \mathrm{mM}$. A mininert valve (Pierce Co.) was screwed on the tube and nitrogen bubbled into the solution for $1 \mathrm{hr}$. A freshly prepared solution of $0.7 \mathrm{M}$ dithiothreitol was injected through the valve to a final concentration of $4 \mathrm{~mm}$ dithiothreitol. Nitrogen was bubbled into the solution for an additional 3-hr period. A freshly prepared solution of $0.7 \mathrm{M}$ iodoacetamide in water was injected through the valve to give a $10 \%$ excess of iodoacetamide over total dithiothreitol and protein sulfhydryls. The glass tube was wrapped in aluminum foil to exclude light and the reaction allowed to proceed for $1 \mathrm{hr}$ while continuing to bubble nitrogen. The reaction was terminated by dialysis which was begun immediately. It was important to maintain oxygen-free conditions throughout the reduction and alkylation procedure to avoid problems later during digestion with trypsin. One sample was alkylated with vinylpyridine (Tarr, 1985) rather than iodoacetamide, but this was not helpful because it made the protein precipitate during digestion. Iodoacetic acid could be used in place of iodoacetamide with equally good results.

Trypsin Digestion. The dialyzed protein in $0.1 \mathrm{M}$ Tris- $\mathrm{Cl}, p \mathrm{H} 8.1$, was digested with trypsin/L-1-tosylamido-2-phenylethyl chloromethyl ketone (Worthington $\mathrm{Co}$.) at $37^{\circ} \mathrm{C}$ for $4 \mathrm{hr}$. The amount of trypsin was $2 \%$ of the weight of cholinesterase. A single addition of trypsin was sufficient to achieve complete digestion. In contrast to the report of Muensch et al. (1978) we did not need to digest longer than $4 \mathrm{hr}$ or make multiple additions of trypsin, nor did the sugar chains of cholinesterase present a problem. We believe that these differences are due to the fact that we achieved complete reduction of disulfides and alkylation of reduced sulfhydryls with our strict anaerobic conditions. This made the protein available to trypsin digestion. Cholinesterase with partly intact disulfide bridges could resemble native cholinesterase, which is known to be extremely resistant to trypsin (Lockridge and $\mathrm{La} \mathrm{Du}$, 1982), probably because of its $24 \%$ carbohydrate content (Haupt et al., 1966).

HPLC to Purify MP-Tryptic Peptide. A Varian HPLC, Model 5060, was used with UV and fluorescence detectors. The MP-tryptic peptide was not fluorescent but it had to be separated from a fluorescent contaminating peptide. Fluorescence excitation passed through an interference filter which had a maximum of $220 \mathrm{~nm}$. Emission passed through a Corning 7-60 glass band filter which included wavelengths 300 to $400 \mathrm{~nm}$, with a maximum at $352 \mathrm{~nm}$. MP-peptide from the usual genotype, UU, was purified as follows: (1) HPLC on a Synchropak RP-P column (Synchrom Co., Linden, Ind.) eluted with a gradient of $0.1 \%$ TFA versus acetonitrile containing $0.075 \%$ TFA as in Fig. $1 \mathrm{~A}-65 \%$ of the applied counts were recovered; (2) HPLC on a 

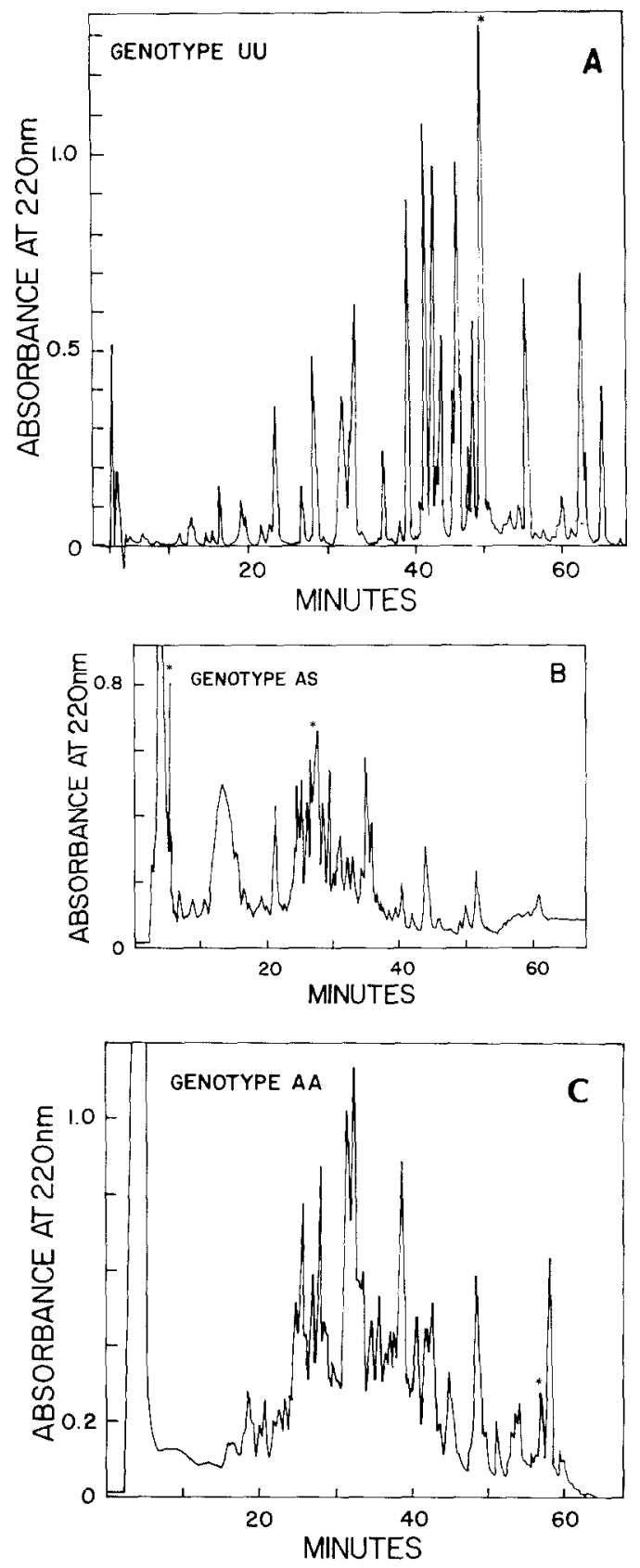

Fig. 1. Isolation of the DFP-labeled tryptic peptide from cholinesterases of various genotypes. A $1.0-\mathrm{ml}$ portion (5 to $10 \mathrm{nmol}$ ) of the 4-hr tryptic digest of the $\left[{ }^{3} \mathrm{H}\right]$ DFP-labeled, $S$ carboxyamidomethylated cholinesterase was applied to the Synchropak RP-P column $(0.41 \times 25$ $\mathrm{cm})$ equilibrated with solvent A $(0.1 \%$ TFA in water). Peptides were eluted with a linear gradient increasing in solvent $\mathrm{B}$ (acetonitrile containing $0.075 \%$ TFA) at a gradient rate of $0.75 \% / \mathrm{min}$. The flow rate was $1 \mathrm{ml} / \mathrm{min}$. Radioactivity is indicated by asterisks. (A) Genotype UU; (B) genotype AS; (C) genotype AA. Protein sylfhydryls in $\mathrm{C}$ were alkylated with vinylpyridine, and the protein was digested with trypsin and $S$. aureus protease. 
Synchropak RP-P column eluted with a gradient of $10 \mathrm{mM} \mathrm{Na} / \mathrm{K}$ phosphate,

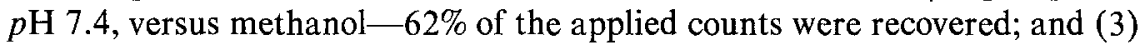
HPLC on a Synchropak RP-P column eluted with a gradient of $0.1 \%$ HFBA versus acetonitrile $-97 \%$ of the applied counts were recovered. It was essential to use a neutral $p \mathrm{H}$ buffer to achieve separation from a fluorescent peptide. The third HPLC step was for desalting and also for additional purification. The overall yield was $39 \%$.

The MP-peptide from the atypical-silent genotype (Fig. 1B) was purified with the same three solvent systems as the usual cholinesterase peptide. The recoveries of applied counts were 34,48 , and $93 \%$, with an overall yield of $15 \%$. The first HPLC step actually yielded $82 \%$ of the applied counts but most of these eluted at the solvent front and only $34 \%$ eluted with the MP-peptide at $27 \mathrm{~min}$.

Conditions for purifying the atypical, AA, MP-peptide were changed because this peptide was found to have different solubility properties. It eluted in a broad peak over $30 \mathrm{~min}$ when $10 \mathrm{mM} \mathrm{Na} / \mathrm{K}$ phosphate, $p \mathrm{H} 7.4$, was used in a gradient with acetonitrile and, furthermore, could not be redissolved in TFA after it had been dried in the presence of a large amount of phosphate salts. In contrast, the usual MP-tryptic peptide eluted in a sharp peak with this same solvent system and was easily dissolved in TFA. The major change in

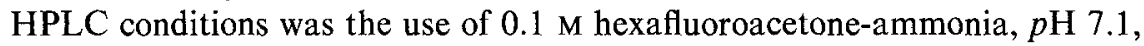
in place of $10 \mathrm{mM} \mathrm{Na} / \mathrm{K}$ phosphate, $p \mathrm{H} \mathrm{7.4.} \mathrm{Hexafluoroacetone} \mathrm{(Aldrich} \mathrm{Co.)}$ has the advantages that it is volatile and transparent at $220 \mathrm{~nm}$ (Tarr and Crabb, 1983) but has the disadvantages that it is toxic and expensive. The atypical (AA) MP-peptide was purified as follows: (1) HPLC on a Synchropak RP-P column eluted with a gradient of $0.1 \%$ TFA versus acetonitrile containing $0.075 \%$ TFA-recovery of the applied counts was $18 \%$; (2) HPLC on a $\mu$ bondapak CN column (Waters Co.) eluted with $0.1 \%$ HFBA versus acetonitrile:1-propanol (3:1)-recovery of the applied counts was 62\%; and (3) HPLC on a $\mu$ bondapak CN column eluted with $0.1 \mathrm{M}$ hexafluoroacetoneammonia, $p \mathrm{H}$ 7.1, versus acetonitrile:1-propanol (3:1)-recovery of the applied counts was $55 \%$. The overall yield was $6 \%$. The low yield in step 1 was due to the use of vinylpyridine to alkylate sulfhydryls. The vinylpyridinederivatized protein precipitated during digestion, although it was in solution in $0.1 \mathrm{M}$ Tris- $\mathrm{Cl}, p \mathrm{H} 8.1$, at the start of digestion.

Amino Acid Analysis. Two commercial laboratories measured the amino acid composition of peptides. They were the AAA Labs, Mercer Island, Wash., under the direction of Dr. Lowell Ericsson, and the University of Michigan Sequencing Facility, Ann Arbor, under the direction of Dr. George Tarr. Salt-free peptides were hydrolyzed for $24 \mathrm{hr}$ at $110^{\circ} \mathrm{C}$ in $\mathrm{HCl}$. Amino acids were quantitated by ninhydrin at the AAA Labs or by derivatization 
with phenylisothiocyanate at the University of Michigan. The latter method was developed by Tarr (1985) and is now marketed by the Waters Co. as the "pico-tag" method. The pico-tag method was used for analyses where the amount of sample was less than $1 \mathrm{nmol}$.

Manual Sequencing. Salt-free peptides were sequenced by Edman degradation using the manual batch method of Tarr (1982). PTH-amino acids were identified by HPLC by the method of Black and Coon (1982), in which one analysis cycle is completed every $16 \mathrm{~min}$.

\section{RESULTS}

HPLC traces of tryptic digests of cholinesterase are shown in Fig. 1, where the MP-tryptic peptide is indicated by radioactive counts. In Fig. 1A the MP-tryptic peptide from the usual genotype eluted at $49 \mathrm{~min}$. A single radioactive peak was obtained. In Fig. $1 B$ the MP-tryptic peptide from the atypical-silent genotype eluted at $26 \mathrm{~min}$. A second radioactive peak eluted at the solvent front. This second radioactive peak was not studied because it was thought to be monoisopropylphosphate released from the preparation during 2 years of storage at $-7^{\circ} \mathrm{C}$, or a very short peptide. In Fig. 1C the MP-tryptic peptide from the atypical, AA, genotype eluted at 54-59 min.

The MP-tryptic peptides were purified by two additional HPLC steps. Table I shows the amino acid composition analysis of the usual (UU), atypical

Table I. Amino Acid Composition of DFP-Labeled Tryptic Peptides Isolated from Usual (UU), Atypical (AA), and Atypical-silent (AS) Variants of Cholinesterase

\begin{tabular}{lcccc}
\hline Amino acid & $\mathrm{UU}^{a, b}$ & $\mathrm{UU}^{c}$ & $\mathrm{AA}^{c}$ & $\mathrm{AS}^{c}$ \\
\hline Ala & $3.1(3)$ & $2.6(3)$ & $3.1(3)$ & $3.0(3)$ \\
Arg & $1.0(1)$ & $0.6(1)$ & $0(0)$ & \\
Glu & $1.2(1)$ & $1.6(1)$ & $0.1(1)$ & $0.9(1)$ \\
Gly & $3.2(3)$ & $3.6(3)$ & $3.0(3)$ & $2.8(2)$ \\
His & $2.1(2)$ & $1.4(2)$ & $0.7(1)$ & \\
Leu & $5.1(5)$ & $5.0(5)$ & $3.9(4)$ & \\
Phe & $2.1(2)$ & $2.0(2)$ & $1.3(1)$ & \\
Pro & $1.0(1)$ & $1.0(1)$ & $1.7(1)$ & \\
Ser & $7.0(7)$ & $7.2(7)$ & $3.8(5)$ & $1.7(2)$ \\
Thr & $2.3(2)$ & $1.4(2)$ & $0.7(1)$ & \\
Val & $2.2(2)$ & $1.9(2)$ & $2.1(2)$ & \\
Total residues & 29 & 29 & 22 & 8 \\
nmol analyzed & 5.0 & 0.25 & 0.58 & 0.45 \\
\hline
\end{tabular}

${ }^{a}$ Values in parentheses were determined from sequence analysis.

${ }^{b}$ Method of detection was ninhydrin.

"Method of detection was "pico-tag." 
(AA), and atypical-silent (AS) MP-tryptic peptides. The peptide from the usual cholinesterase contained 29 residues, atypical contained 22 residues, and atypical-silent contained 8 residues.

Manual sequence analysis of the usual peptide (Table II) yielded data for the first 19 residues. Half of each PTH-amino acid sample was counted, and the radioactive counts showed that DFP was attached to serine at the eighth position from the $\mathbf{N}$ terminal. The radioactive label was not cleaved off during Edman degradation to a significant extent. To obtain the complete sequence, the MP-tryptic peptide was subfragmented. The peptide was digested with chymotrypsin and the subfragments were separated on a C18 $\mu$ bondapak (Waters Co.) column. Sequencing results are in Table III. The data in Table III provided important overlapping peptides which aligned the subfragments obtained in the following digestion with pepsin. The MP-tryptic peptide was subfragmented with pepsin and the subfragments were separated as shown in Fig. 2. Sequencing results are given in Table IV. Subfragment P6 was analyzed for amino acid composition (Table V) because it contained a particularly difficult sequence, Ser-His-Ser. The data established that the sequence for the usual genotype was Ser-Val-Thr-Leu-Phe-Gly-Glu-Ser-

Table II. Manual Sequence Analysis of the DFP-Labeled Tryptic Peptide Isolated from Usual Cholinesterase ${ }^{a}$

\begin{tabular}{clcr}
\hline $\begin{array}{c}\text { Edman } \\
\text { cycle }\end{array}$ & $\begin{array}{c}\text { Assigned } \\
\text { amino acid }\end{array}$ & $\begin{array}{c}\text { Yield of PTH } \\
\text { amino acid (pmol) }\end{array}$ & cpm $^{b}$ \\
\hline 1 & Ser & 459 & 8,085 \\
2 & Val & 1742 & 6,842 \\
3 & Thr & 660 & 16,985 \\
4 & Leu & 727 & 9,939 \\
5 & Phe & 1828 & 7,300 \\
6 & Gly & 200 & 6,176 \\
7 & Glu & 440 & 10,566 \\
8 & Ser-[ ${ }^{3}$ H]MP & - & 568,188 \\
9 & Ala & 329 & 150,204 \\
10 & Gly & 806 & 65,133 \\
11 & Ala & 317 & 27,830 \\
12 & Ala & 181 & 10,419 \\
13 & Ser & - & 19,927 \\
14 & Val & 257 & 2,471 \\
15 & Ser & - & 7,001 \\
16 & Leu & 87 & \\
17 & His & 148 & \\
18 & Leu & 50 & \\
19 & Leu & 49 & \\
\hline
\end{tabular}

${ }^{a}$ This peptide was sequenced four times, using $27,10,8$, and 8 nmol peptide.

${ }^{b}$ Radioactivity, expressed as counts per minute (cpm), was determined for each PTH-amino acid by liquid scintillation counting. 
Table III. Manual Sequence Analysis of Chymotryptic Subfragments of the Usual DFP-Labeled Tryptic Peptide ${ }^{a}$

\begin{tabular}{|c|c|c|c|c|c|c|c|c|}
\hline $\begin{array}{l}\text { Edman } \\
\text { cycle }\end{array}$ & & & & & & & & \\
\hline 1 & S 2073 & G 2143 & G 1907 & A 1230 & H 3415 & L 1090 & L 6127 & S 6267 \\
\hline 2 & V 2615 & E 2691 & Е 2067 & S 1453 & L 5738 & S 1347 & L 6780 & L 21976 \\
\hline 3 & T 4063 & S 453 & $\mathrm{~S}-{ }^{3} \mathrm{H}-\mathrm{DFP}$ & V 728 & L 5454 & P 775 & S 5364 & F 7256 \\
\hline 4 & L 2167 & A 71 & A 987 & S 102 & S 297 & G 176 & P 1744 & \\
\hline 5 & F 1973 & G 150 & G 539 & & & S 76 & G 617 & \\
\hline 6 & & & A 549 & & & & S 389 & \\
\hline 7 & & & A 710 & & & & H 440 & \\
\hline 8 & & & S 30 & & & & & \\
\hline 9 & & & V 363 & & & & & \\
\hline 10 & & & S 148 & & & & & \\
\hline 11 & & & L 194 & & & & & \\
\hline $\begin{array}{l}\text { No. of times } \\
\text { sequenced }\end{array}$ & 1 & 2 & 2 & 1 & 1 & 1 & 1 & 1 \\
\hline
\end{tabular}

${ }^{a}$ The PTH-amino acid observed by HPLC analysis for each Edman degradation cycle is shown. The number that follows each residue is the yield in picomoles.

Ala-Gly-Ala-Ala-Ser-Val-Ser-Leu-His-Leu-Leu-Ser-Pro-Gly-Ser-His-SerLeu-Phe-Thr-Arg.

Sequence analysis (Table VI) of the MP-tryptic peptide isolated from the atypical-silent cholinesterase in Fig. 1B showed that the sequence was Gly-Glu-Ser-Ala-Gly-Ala-Ala-Ser. Table VI shows that DFP is attached to the serine at cycle 3 .

The atypical, AA, MP-peptide was subfragmented by digestion with pepsin. The sequence results are given in Table VII. The atypical sequence was Ser-Val-Thr-Leu-Phe-Gly-Glu-Ser-Ala-Gly-Ala-Ala-Ser-Val-Ser-LeuHis-Leu-Leu-Ser-Pro-Gly.

\section{DISCUSSION}

We have isolated and sequenced the DFP-labeled tryptic peptides from three genetic types of human serum cholinesterase: the usual (UU), atypical (AA), and atypical-silent (AS). Their sequences are compared in Table VIII. The usual cholinesterase yielded a 29-residue peptide which is probably the complete tryptic peptide since it terminated in arginine. The 22 residues of atypical and 8 residues of atypical-silent exactly matched portions of the usual peptide. There were no amino acid substitutions. Of special note was the presence of glutamic acid in position 7 from the $\mathrm{N}$ terminal in all three sequences. This is of interest because Yamato et al. (1983) had suggested that atypical cholinesterase contained histidine in place of glutamic acid at this 


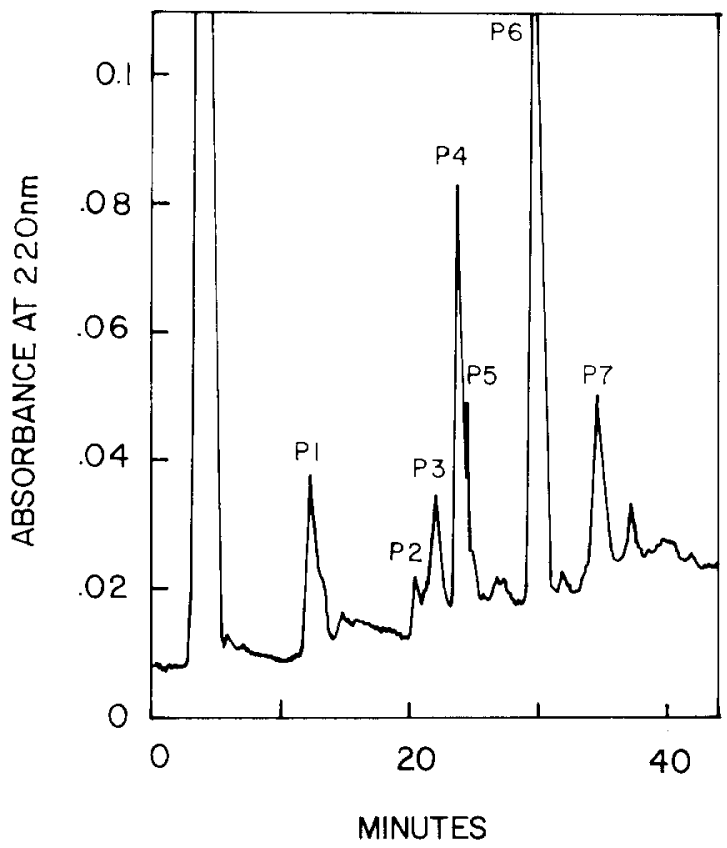

Fig. 2. HPLC of pepsin subfragments of the DFP-labeled tryptic peptide isolated from genotype UU cholinesterase. The MP-tryptic peptide, containing $26.9 \mathrm{nmol}$ and $15,200,000 \mathrm{cpm}$, was dissolved in $10 \mu \mathrm{l}$ of $88 \%$ formic acid and then diluted with $200 \mu 1$ of water. Nineteen microliters of a freshly prepared pepsin solution, $1 \mathrm{mg} / \mathrm{ml}$, was added. Digestion was for $3 \mathrm{hr}, 45 \mathrm{~min}$ at room temperature. The entire sample was injected into a $\mathrm{C} 18$ Waters column equilibrated with solvent A (0.1\% TFA in water). Peptides were eluted with a linear gradient increasing in solvent $B$ (acetonitrile containing $0.075 \%$ TFA) at a gradient rate of $0.75 \%$ / $\mathrm{min}$. The flow rate was $1 \mathrm{ml} / \mathrm{min}$. Seventy-four percent of the applied counts were recovered.

Table IV. Manual Sequence Analysis of the Pepsin Subfragments of the Usual DFP-Labeled Tryptic Peptide ${ }^{a}$

\begin{tabular}{cccccc}
\hline $\begin{array}{c}\text { Edman } \\
\text { cycle }\end{array}$ & P3 & P4 & P2 & P6 & P1 \\
\hline 1 & Ser 1790 & Phe 1075 & Val 1376 & His 694 & Phe 1058 \\
2 & Val 2334 & Gly 928 & Ser 355 & Leu 1024 & Thr 253 \\
3 & Thr 1086 & Glu 877 & Leu 695 & Leu 1081 & Arg 372 \\
4 & Leu 2511 & Ser-[3]DFP & & Ser 571 & \\
5 & & Ala 1724 & & Pro 772 & \\
6 & & Gly 589 & & Gly 510 & \\
7 & & Ala 725 & & Ser 203 & \\
8 & & Ala 586 & & His 111 & \\
9 & & Ser 247 & & Ser 140 & \\
10 & & & & Leu 201 & \\
No. of times & 2 & & & & \\
sequenced & & & & & \\
\hline
\end{tabular}

${ }^{a}$ The PTH-amino acid observed by HPLC analysis for each Edman degradation cycle is shown. The number that follows each residue is the yield in picomoles. 
Table V. Amino Acid Composition of Pepsin Subfragment P6 of the Usual DFP-Labeled Tryptic Peptide

\begin{tabular}{lc}
\hline Amino acid & $\mathrm{P}^{a}$ \\
\hline Gly & $1.2(1)^{b}$ \\
His & $1.7(2)$ \\
Leu & $3.0(3)$ \\
Pro & $1.1(1)$ \\
Ser & $3.5(3)$ \\
Total residues & 10 \\
nmol analyzed & 0.83 \\
\hline
\end{tabular}

${ }^{a}$ Method of detection was "pico-tag."

${ }^{b}$ Values in parentheses were determined from sequence analysis.

position. The sequence obtained by Yamato et al. (1983) for the active site of usual human serum cholinesterase was Gly-Glu-Ser-Ala-Gly-Ala-Ser-AlaVal-Ser-Leu. In our sequence the order of Ser and Ala in positions 7 and 8 is reversed.

The differences in the lengths of the peptides can probably be attributed to protease or peptidase contaminants in the AS and AA cholinesterase preparations. Contaminants are suspected because the AS and AA peptides were not the result of cleavage by trypsin since they did not terminate in Arg or Lys. The identity of the protease contaminant is unknown. Nausch and Heymann (1985) demonstrated that dipeptidylaminopeptidase IV can copurify with cholinesterase. Since this enzyme cleaves two amino acids at a time from the $\mathrm{N}$ terminal, other contaminants must be responsible for the missing amino acids. Five amino acids are presumed missing from the $\mathrm{N}$ terminal of AS. Seven and 16 amino acids are presumed missing from the $\mathrm{C}$ terminals.

Table VI. Manual Sequence Analysis of the DFP-Labeled Tryptic Peptide Isolated From Atypical-Silent Cholinesterase ${ }^{a}$

\begin{tabular}{clcc}
\hline $\begin{array}{c}\text { Edman } \\
\text { cycle }\end{array}$ & $\begin{array}{c}\text { Assigned } \\
\text { amino acid }\end{array}$ & $\begin{array}{c}\text { Yield of PTH } \\
\text { amino acid (pmol) }\end{array}$ & cpm $^{b}$ \\
\hline 1 & Gly & 100 & 6,608 \\
2 & Glu & 90 & 4,185 \\
3 & Ser-[ ${ }^{3}$ H]MP & & 22,966 \\
4 & Ala & 92 & 14,841 \\
5 & Gly & 70 & 7,483 \\
6 & Ala & 67 & 3,595 \\
7 & Ala & 60 & \\
8 & Ser & 224 & \\
\hline
\end{tabular}

${ }^{a}$ This peptide was sequenced three times, using 122,100 , and 75 pmol peptide.

${ }^{b}$ Radioactivity, expressed as counts per minute (cpm), was determined for each PTH-amino acid by liquid scintillation counting. 
Table VII. Manual Sequence Analysis of the Pepsin Subfragments of the Atypical DFP-Labeled Tryptic Peptide ${ }^{a}$

Edman cycle

\begin{tabular}{cclll}
\hline 1 & Ser 507 & Phe 1111 & Val 848 & His 192 \\
2 & Val 1536 & Gly 668 & Ser 264 & Leu 340 \\
3 & Thr 502 & Glu 693 & Leu 419 & Leu 355 \\
4 & Leu 938 & Ser-[ ${ }^{3}$ H]MP & & Ser 45 \\
5 & & Ala 488 & & Pro 244 \\
6 & & Gly 448 & & Gly 196 \\
7 & & Ala 335 & & \\
8 & & Ala 403 & & \\
9 & & Ser 191 & 2 & \\
No. of times & 1 & & & \\
sequenced & & & & \\
\hline
\end{tabular}

${ }^{a}$ The PTH-amino acid observed by HPLC analysis for each Edman degradation cycle is shown. The number that follows each residue is the yield in picomoles.

As the complete tryptic peptide was not obtained from the atypical variant, one might argue that an amino acid substitution might be present in the missing seven residues. Our work does not rule out this possibility, but neither does it support it. Our results explain how DFP-labeled peptides from atypical and usual cholinesterases can have different solubilities, charges, and mobilities and still contain no amino acid substitutions. This leaves no reason for expecting the location of an amino acid alteration to be in the DFP-labeled peptide of atypical cholinesterase, as opposed to any other region in the 580 amino acid subunit. The mutation might be anywhere in the linear sequence, although in a three dimensional projection we expect it to be approximately 5 $\AA$ from the active-site serine. This expectation is based on the estimated distance between the anionic-site and the active-site serine (Wilson and Quan, 1958).

The atypical-silent cholinesterase molecule contains two genetically different subunits. It contains atypical subunits and silent subunits. It is likely that the DFP-labeled peptide from our AS sample originated from atypical

Table VIII. Active-Site Sequences for Usual, Atypical, and Atypical-Silent Human Cholinesterase Genotypes

\begin{tabular}{lc}
\hline \multicolumn{1}{c}{ Genotype } & Sequence $^{a}$ \\
\hline & $*$ \\
Usual & SVTLFGESAGAASVSLHLLSPGSHSLFTR \\
Atypical & SVTLFGESAGAASVSLHLLSPG \\
Atypical-silent & GESAGAAS \\
\hline
\end{tabular}

${ }^{a}$ The * denotes site of DFP binding. 
subunits alone. Evidence for this conclusion comes from the stoichiometry of DFP binding which was calculated for our DFP-labeled, aged, cholinesterase preparations. Two AS samples bound 0.31 and $0.33 \mathrm{~mol}$ of DFP $/ \mathrm{mol}$ of subunit. Two UU samples bound 0.80 and $0.76 \mathrm{~mol}$ of DFP $/ \mathrm{mol}$ of subunit. The label had been aged so one would expect less than one equivalent bound per subunit. The significantly lower stoichiometry for DFP binding in the AS samples, compared to the UU samples, suggests that the silent subunits did not bind DFP. This is not surprising since silent cholinesterase from some donors has zero activity (Liddell et al., 1962). Silent cholinesterase from other donors has been reported to have 1 to $3 \%$ of normal activity (Altland and Goedde, 1970; Rubinstein et al., 1970) and therefore may be expected to bind DFP.

The single DFP-labeled peptide we observed is consistent with other evidence (Lockridge et al., 1979) that the four subunits of cholinesterase are identical.

The active-site peptide is highly unusual in its high content of serine and threonine, which total 9 residues of 29. Since PTH-serine and PTH-threonine were obtained in a low yield from Edman degradation, the active-site peptide was difficult to sequence and had to be subfragmented to get the complete sequence.

The active-site tryptic peptide of acetylcholinesterase isolated from the electric organ of Torpedo californica is Thr-Val-Thr-Ile-Phe-Gly-Glu-SerAla-Gly-Gly-Ala-Ser-Val-Gly-Met-His-Ile-Leu-Ser-Pro-Gly-Ser-Arg (MacPhee-Quigley et al., 1985). There is a remarkable degree of homology with the human serum cholinesterase active-site peptide, as 17 of 24 residues are identical, and 3 are conservative substitutions. The active-site peptide from horse serum cholinesterase (Jansz et al., 1959), Phe-Gly-Glu-Ser-Ala-Gly(Ala-Ala-Ser), is identical to a portion of the peptide from human serum cholinesterase.

The results reported here provide the longest sequence information available to date for a cholinesterase of human origin. This should help to distinguish human butyrylcholinesterase from acetylcholinesterase when these are isolated as DNA clones and should, therefore, be useful to the cloning work already in progress in various laboratories.

\section{ACKNOWLEDGMENT}

We thank Dr. Clarence A. Broomfield for critically reviewing the manuscript.

\section{REFERENCES}

Altland, K., and Goedde, H. W. (1970). Heterogeneity in the silent gene phenotype of pseudocholinesterase of human serum. Biochem. Genet. 4:321. 
Berends, F., Posthumus, C. H., Sluys, I. V. D., and Deierkauf, F. A. (1959). The chemical basis of the "ageing process" of DFP-inhibited pseudocholinesterase. Biochim. Biophys. Acta 34:576.

Black, S. D., and Coon, M. J. (1982). Simple, rapid, and highly efficient separation of amino acid phenylthiohydantoins by reversed-phase high-performance liquid chromatography. Anal. Biochem. 121:281.

Harris, H., and Whittaker, M. (1961). Differential inhibition of human serum cholinesterase with fluoride: Recognition of two new phenotypes. Nature 191:496.

Haupt, H., Heide, K., Zwisler, O., and Schwick, H. G. (1966). Isolierung und physikalischchemische Charakterisierung der Cholinesterase aus Humanserum. Blut 14:65.

Hersh, L. B., Raj, P. P., and Ohlweiler, D. (1974). Kinetics of succinylcholine hydrolysis by serum cholinesterase: Comparison to dibucaine and succinylcholine numbers. J. Pharmacol. Exp. Ther. 189:544.

Jansz, H. S., Brons, D., and Warringa, M. G. P. J. (1959). Chemical nature of the DFP-binding site of pseudocholinesterase. Biochim. Biophys. Acta 34:573.

Kalow, W., and Davies, R. O. (1958). The activity of various esterase inhibitors towards atypical human serum cholinesterase. Biochem. Pharmacol. 1:183.

Kalow, W., and Genest, K. (1957). A method for the detection of atypical forms of human serum cholinesterase. Determination of dibucaine numbers. Can. J. Biochem. Physiol. 35:339.

Kalow, W., and Gunn, D. R. (1957). The relation between dose of succinylcholine and duration of apnea in man. J. Pharmacol. Exp. Ther. 120:203.

Kalow, W., and Gunn, D. R. (1959). Some statistical data on atypical cholinesterase of human serum. Ann. Hum. Genet. 23:239.

Kalow, W., and Lindsay, H. A. (1955). A comparison of optical and manometric methods for the assay of human serum cholinesterase. Can. J. Biochem. Physiol. 33:568.

Liddell, J., Lehmann, H., and Silk, E. (1962). A "silent" pseudocholinesterase gene. Nature 193:561.

Lockridge, O., and La Du, B. N. (1978). Comparison of atypical and usual human serum cholinesterase. Purification, number of active sites, substrate affinity, and turnover number. J. Biol. Chem. 253:361.

Lockridge, O., and La Du, B. N. (1982). Loss of the interchain disulfide peptide and dissociation of the tetramer following limited proteolysis of native human serum cholinesterase. J. Biol. Chem. 257:12012.

Lockridge, O., Eckerson, H. W., and La Du, B. N. (1979). Interchain disulfide bonds and subunit organization in human serum cholinesterase. J. Biol. Chem. 254:8324.

MacPhee-Quigley, K., Taylor, P., and Taylor, S. (1985). Primary structure of the catalytic subunits from two molecular forms of acetylcholinesterase. A comparison of $\mathrm{NH}_{2}$-terminal and active center sequences. J. Biol. Chem. 260:12185.

Muensch, H., Yoshida, A., Altland, K., Jensen, W., and Goedde, H.-W. (1978). Structural difference at the active site of dibucaine resistant variant of human plasma cholinesterase. Am. J. Hum. Genet. 30:302.

Nausch, I., and Heymann, E. (1985). Substance P in human plasma is degraded by dipeptidyl peptidase IV, not by cholinesterase. J. Neurochem. 44:1354.

Rubinstein, H. M., Dietz, A. A., Hodges, L. K., Lubrano, T., and Czebotar, V. (1970). Silent cholinesterase gene: Variations in the properties of serum enzyme in apparent homozygotes. J. Clin. Invest. 49:479.

Tarr, G. E. (1982). In Elzinga, M. (ed.), Methods in Protein Sequence Analysis, Humana Press, Clifton, N.J., pp. 223-232.

Tarr, G. E. (1986). In Shively, J. E. (ed.), Microcharacterization of Polypeptides: A Practical Manual, Humana Press, Clifton, N.J. (in press).

Tarr, G. E., and Crabb, J. W. (1983). Reverse-phase high-performance liquid chromatography of hydrophobic proteins and fragments thereof. Anal. Biochem. 131:99.

Wilson, I. B., and Quan, C. (1958). Acetylcholinesterase studies on molecular complementariness. Arch. Biochem. Biophys. 73:131.

Yamato, K., Huang, I.-Y., Muensch, H., Yoshida, A., Goedde, H.-W., and Agarwal, D. P. (1983). Amino acid sequence of the active site of human pseudocholinesterase. Biochem. Genet. 21:135. 